\title{
Primer coronariaintervenció ST-elevációs infarktusban
}

\author{
Változások öt év alatt
}

\author{
Voith László dr. - Édes István Ferenc dr. - Nowotta Fanni dr. \\ Skoda Réka dr. - Bárczi György dr. - Merkely Béla dr. - Becker Dávid dr. \\ Semmelweis Egyetem, Városmajori Szív- és Érgyógyászati Klinika, Budapest
}

\begin{abstract}
Bevezetés: Heveny myocardialis infarctusban a szívizommentés sikere, a beteg életkilátása nagymértékben függ a panasz kezdete és az elzáródott koszorúér rekanalizálása között eltelt ischaemiás időtől. Jelenleg az ér nyitása optimális esetben minden betegnél koszorúér-intervencióval történik.

Célkitüzés: Annak vizsgálata, hogy öt év alatt mennyit változtak az ischaemiás idő összetevői, és miben változott az elzáródott ér nyitásának módszere ST-elevációs myocardialis infarctus (STEMI) miatt végzett primer coronariaintervencióban.

Módszer: 2014. 01. 01. és 2018. 12. 31. között 1663, STEMI miatt koszorúér-intervencióval kezelt betegnél (1173 férfi és 490 nő) vizsgáltuk évenkénti bontásban a panasztól a koszorúér nyitásáig eltelt idő összetevőit és a 30 napos halálozást.

Eredmények: Öt év alatt a panasztól az első egészségügyi kontaktusig medián 2:53 vs. 2:10 óra ( p = 0,0132), ettől az intervenciós centrumba történt felvételig medián 1:17 vs. 1:03 óra $(\mathrm{p}=0,009)$, a felvételtől a ballon nyitásáig medián 0:31 vs. 0:29 óra $(\mathrm{p}=\mathrm{ns})$ telt el. A panasztól a ballon nyitásáig eltelt idő (medián 5:29 vs. 4:07 óra, $\mathrm{p}=0,0001$ ) rövidült, döntően 2014 és 2015 között. A gyógyszerkibocsátó stent beültetése 15\%-ról 96\%-ra nőtt. A vizsgált években a légzés/keringés támogatás aránya 8,2-10,6-13,9-7,6-8,4, a 30 napos halálozásé 4,1-6,8-11,1-7,4-5,7\% volt; a két érték korrelációt mutat $(\mathrm{p}=0,827)$.

Következtetés: Öt év alatt a panasztól az első egészségügyi kontaktusig és a kórházi beszállításig eltelt idő rövidült, de az Európai Kardiológiai Társaság ajánlásához képest hosszú; a kórházi felvételtól a ballon nyitásáig eltelt idő megfelelő. A négy órán belüli reperfúzió a betegek közel felében valósult meg. Az intervenciós centrumba való gyorsabb bekerülés javíthatna az eredményen.
\end{abstract}

Orv Hetil. 2021; 162(13): 497-503

Kulcsszavak: myocardialis infarctus, primer coronariaintervenció, idősor-analízis

\section{Primary coronary intervention in ST-elevation myocardial infarction}

\section{Changes in five years}

Introduction: In acute myocardial infarction, the heart muscle salvage, the patient's life expectancy is highly dependent on the elapsed ischaemic time from the onset of complaint to target vessel recanalisation. Nowadays, target vessel recanalisation is performed with coronary intervention in all patients in optimal case.

Objective: To examine how the components of ischemic time and the opening procedure of the occluded coronary have changed over five years in primary intervention done in acute ST-elevation myocardial infarction (STEMI). Method: Authors studied data of 1663 (1173 male and 480 female) STEMI patients in annual breakdowns treated with coronary intervention between 01. 01. 2014 and 31. 12.2018, time from complaint to coronary artery opening, details of intervention and 30 days mortality rate.

Results: During the five years, time intervals were as follows: from onset of complaint to first medical contact: median $2: 53$ vs. $2: 10$ hours $(\mathrm{p}=0.0132)$, from this to admission in the interventional centre: median 1:17 vs. 1:03 hours $(\mathrm{p}=0.009)$, from hospital admission to balloon opening: median 0:31 vs. 0:29 hours $(\mathrm{p}=\mathrm{ns})$. In total, the complaint to balloon opening time (median 5:29 vs. 4:07 hours, $\mathrm{p}=0.0001$ ) diminished, decisively from 2014 to 2015. Ratio of drug-eluting stent implantation increased from $15 \%$ to $96 \%$. In the investigated years, the need of respiratory and/or circulatory device support ratio was 8.2-10.6-13.9-7.6-8.4, 30-day mortality rate between 4.16.8-11.1-7.4-5.7\%; these two values showed a correlation $(\mathrm{p}=0.827)$. 
Conclusion: The time from complaint to first medical contact and transfer to hospital against the significant decrease is still longer than the recommendation of the European Society of Cardiology. The time from hospital admission to balloon opening is adequate. Reperfusion within four hours was achieved in half of the patients in total. Faster hospitalization may improve results.

Keywords: myocardial infarction, primary coronary intervention, time series analysis

Voith L, Édes IF, Nowotta F, Skoda R, Bárczi Gy, Merkely B, Becker D. [Primary coronary intervention in ST-elevation myocardial infarction. Changes in five years]. Orv Hetil. 2021; 162(13): 497-503.

(Beérkezett: 2020. május 17.; elfogadva: 2020. szeptember 22.)

\section{Rövidítések}

$\mathrm{AMI}=$ akut myocardialis infarctus; $\mathrm{BMS}=($ bare metal stent $)$ fémhálós stent; DES = (drug-eluting stent) gyógyszerkibocsátó stent; $\mathrm{ECMO}=$ extracorporalis membránoxigenizátor; $\mathrm{EKG}=$ elektrokardiográfia; Eü-F = az első egészségügyi kontaktustól az intervenciós centrumba történt felvételig eltelt idő; $\mathrm{F}-\mathrm{B}=\mathrm{az}$ intervenciós centrumba történt felvételtől a PTCA-s ballon nyitásáig eltelt idő; IABP = intraaorticus ballonpumpa; $\mathrm{IPPB}=$ (intermittent positive pressure breathing) intermittáló, pozitív nyomású lélegeztetés; $\mathrm{P}-\mathrm{B}=$ totális ischaemiás idő (a P-Eü, az Eü-F és az F-B összesen); P-Eü = a panasz kezdetétől az első egészségügyi kontaktusig eltelt idő; $\mathrm{PCI}=$ percutan coronariaintervenció $;$ pPCI = primer PCI; PTCA = percutan coronariaangioplastica; STEMI = ST-elevációs myocardialis infarctus; TAJ = társadalombiztosítási azonosító jel

Akut szívizominfarktusban a kezelés két alapvető célja a beteg életben tartása és a szívizom-károsodás csökkentése. Az első eléréséhez több lehetőség áll rendelkezésre: az ingerképzési-ingervezetési zavarok defibrillálással, pacemakerkezeléssel történő kivédése, a légzés és keringés támogatása respirátorral (IPPB), illetve a döntően a bal kamra múködését támogató eszközökkel: intraaorticus ballonpumpa (IABP), extracorporalis membránoxigenizátor (ECMO). A második cél az elzáródott koszorúér minél rövidebb idő alatt történő rekanalizálásával érhető el. Jelenleg a fejlett egészségüggyel rendelkező országokban a rekanalizálás világszerte primer percutan coronariaintervencióval (pPCI) történik, megfelelő személyi és tárgyi feltételekkel rendelkező centrumokban.
A panasz kezdetétól a rekanalizálásig eltelő idő összetevői: jelentkezés egészségügyi szolgáltatónál, beszállítás intervenciót végző kórházba és a beavatkozás elvégzéséhez szükséges időintervallumok összege. A vizsgált öt év alatt az összetevők változtak: a betegek valamivel hamarabb jelentkeznek, az egészségügyi közremúködők nagyobb gyakorlata és az eszközök fejlesztése miatt a diagnózis felállítása, a légzés/keringés támogatása és az intervenció elvégzése könnyebbé vált.

\section{Betegek és módszer}

A betegválasztás kritériumai: ST-elevációs myocardialis infarctus (STEMI), az első pPCI, TAJ-szám megléte (hiánya a beteg nyomon követését akadályozza), ismert panaszkezdet, az első egészségügyi kontaktus, a nálunk történő kórházi felvétel és ballonnyitás időpontjai. 2014. 01. 01. és 2018. 12. 31. között az általunk STEMI-ben végzett 2766 koszorúér-intervenció közül 1663 beteg (1173 férfi és 490 nő) adatai feleltek meg a fenti kritériumoknak. A továbbiakban a nemek szerinti megoszlást nem vizsgáltuk.

A betegeknél a prehospitális időszakban szisztémás thrombolysis nem történt.

Évenkénti bontásban elemeztük a panasztól az első egészségügyi kontaktusig (P-Eü), ettől az intervenciós centrumba történt felvételig (Eü-F), a felvételtól a ballon nyitásáig $(\mathrm{F}-\mathrm{B})$ eltelt idő hosszát, a részintervallumok összegét $(\mathrm{P}-\mathrm{B})$, azaz a totális ischaemiás időt, a légzés/keringés támogatást (IPPB/IABP/ECMO), a 30

1. táblázat | A betegek száma, átlagos kora, a férfiak (Ffi) és a primer felvétel aránya, a panasztól az első EKG-ig (P-Eü), ettől az intervenciós centrumba történt felvételig (Eü-F), a felvételtől a ballon nyitásáig (F-B) eltelt idő, ezek összegének (P-B) medián (MED) értékei óra:percben, a légzés- és/vagy keringéstámogatott betegek $(\mathrm{L} / \mathrm{K}$ ) és a 30 napon belül meghaltak (Exitus) száma

\begin{tabular}{|c|c|c|c|c|c|c|c|c|c|c|}
\hline & Beteg & $\begin{array}{c}\text { Korátlag } \\
\text { (év) }\end{array}$ & $\begin{array}{l}\text { Ffi } \\
\%\end{array}$ & $\begin{array}{c}\text { Primer } \\
\%\end{array}$ & $\begin{array}{l}\text { P-Eü } \\
\text { MED }\end{array}$ & $\begin{array}{l}\text { Eü-F } \\
\text { MED }\end{array}$ & $\begin{array}{c}\text { F-B } \\
\text { MED }\end{array}$ & $\begin{array}{c}\text { P-B } \\
\text { MED }\end{array}$ & $\begin{array}{c}\mathrm{L} / \mathrm{K} \\
\text { támogatás }\end{array}$ & $\begin{array}{l}\text { Exitus } \\
<30 \text { nap }\end{array}$ \\
\hline 2014 & 268 & 62,3 & 68,3 & 81,3 & $2: 53$ & $1: 17$ & $0: 31$ & $5: 29$ & 22 & 11 \\
\hline 2015 & 309 & 62,2 & 68,1 & 80,9 & $2: 00$ & $1: 13$ & $0: 30$ & $4: 20$ & 33 & 21 \\
\hline 2016 & 368 & 63,6 & 66,8 & 87,8 & $2: 02$ & 1:08 & $0: 30$ & $4: 15$ & 51 & 41 \\
\hline 2017 & 373 & 62,7 & 64,3 & 83,6 & $1: 53$ & 1:06 & $0: 29$ & $4: 12$ & 28 & 28 \\
\hline 2018 & 345 & 62,4 & 69,9 & 86,7 & $2: 10$ & 1:03 & $0: 29$ & 4:07 & 29 & 27 \\
\hline
\end{tabular}


napos halálozást, a pPCI során beültetett stent fajtáját - fémhálós stent (BMS) vagy gyógyszerkibocsátó stent (DES) -, a Semmelweis Egyetem MedSol-rendszerében és a Nemzeti Szívinfarktus Regiszterben általunk korábban rögzített adatok alapján (1. táblázat).

$\mathrm{Az}$ idősor elemzéséhez a Statistica 13.2 programot (StatSoft Inc., Tulsa, OK, Amerikai Egyesült Államok) használtuk. A percben levő értékek mediánjának összehasonlítását nonparametrikus medián teszttel, a minőségi változók függetlenségi vizsgálatát khi-négyzet-próbával végeztük, majd a percben kapott időintervallumokat óra:perc értékekre konvertáltuk.

\section{Eredmények}

Az évenkénti bontásban vizsgált időintervallumok - a panasz kezdetétől az első egészségügyi kontaktusig eltelt idő (2:53 vs. $2: 10, \mathrm{p}=0,013)$ (1. ábra) és az ettől az időponttól a kórházi felvételig eltelt idő (1:17 vs. 1:03, $\mathrm{p}=0,009$ ) (2. ábra) - öt év alatt csökkentek, elsósorban a 2014-2015. évi adatokban. A primer és a szekunder felvétellel bekerült betegek időintervallumai között lényeges különbség látható.

Intézetünkben a kórházi felvételtől a ballon nyitásáig eltelt idő medián értéke öt év alatt mérsékelten csökkent, 0:31 óráról 0:29 órára, ez statisztikailag nem szignifikáns.

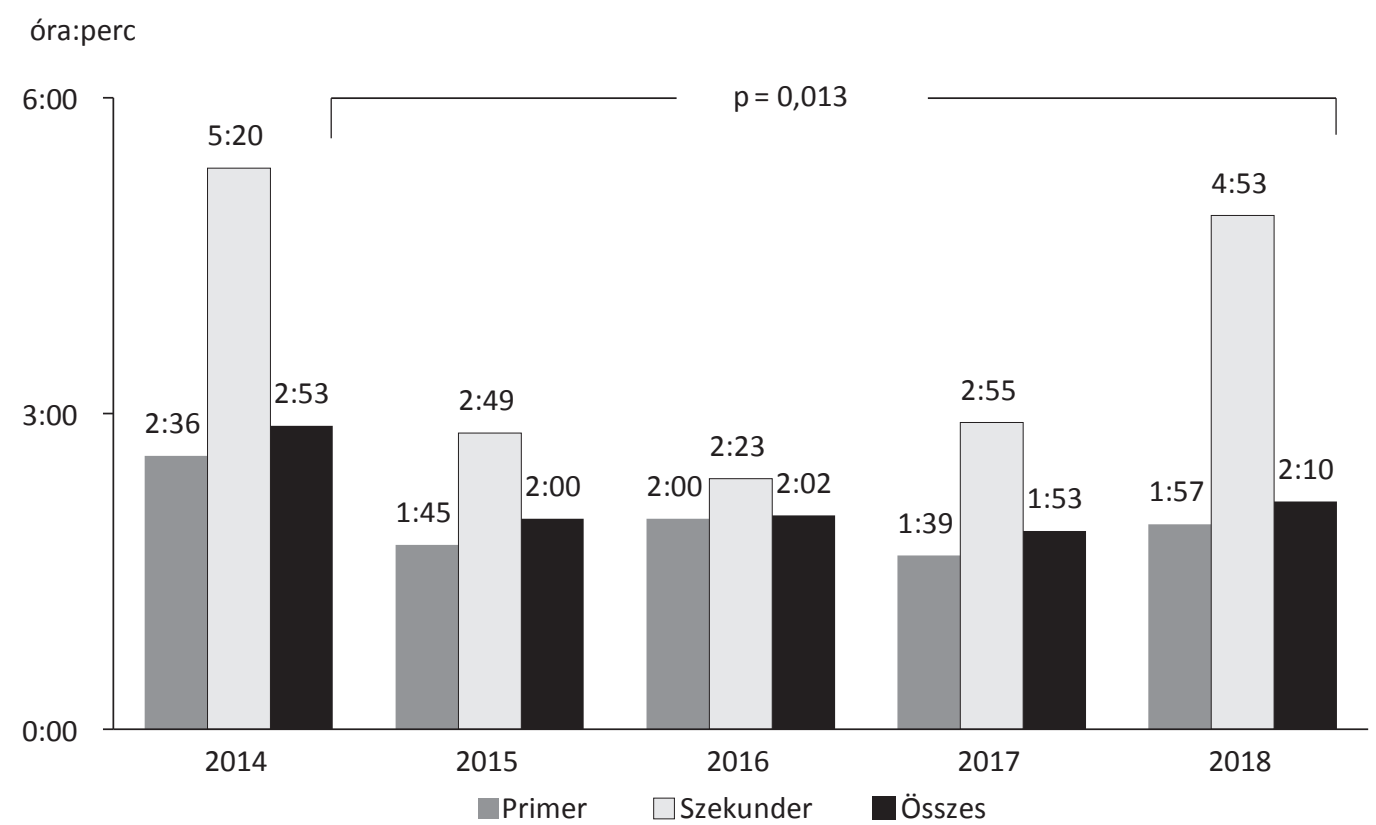

1. ábra $\quad$ A panasz kezdetétől az első egészségügyi kontaktusig eltelt idő medián értékei a primeren és a szekunder beutalással felvett, valamint az összes betegnél (óra:perc)

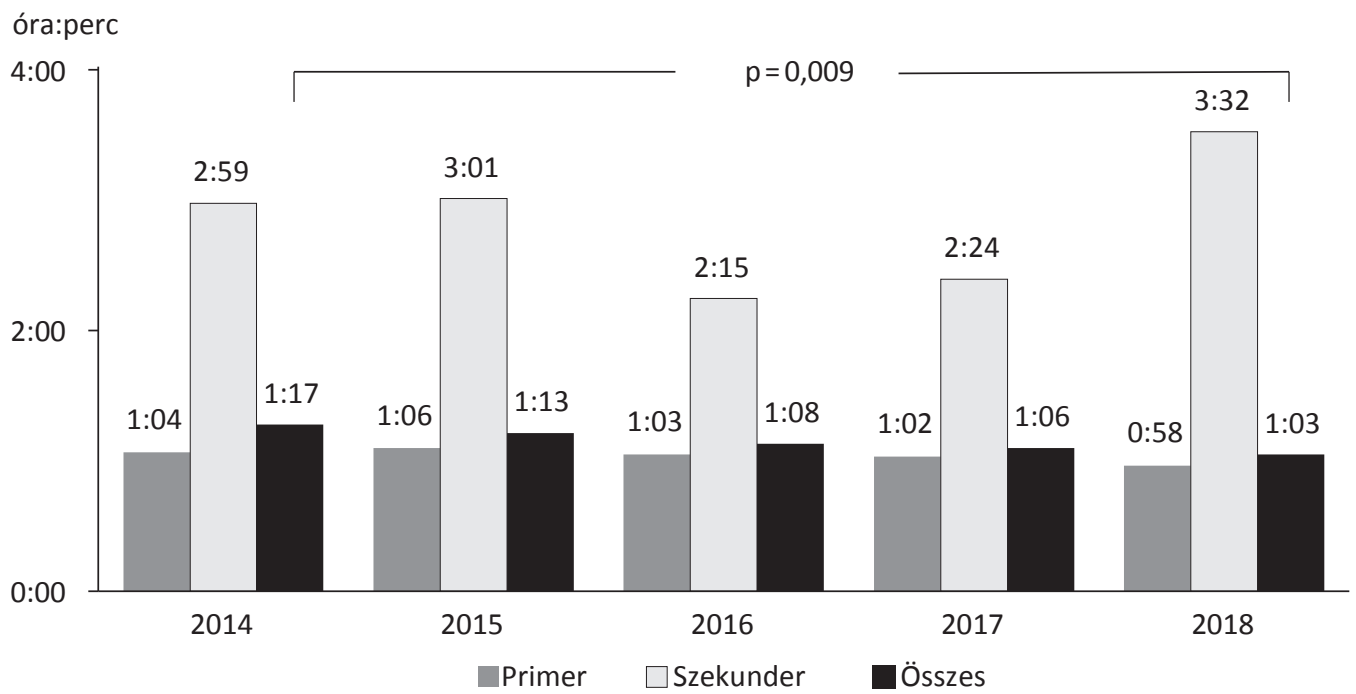

2. ábra $\quad$ Az első egészségügyi kontaktustól az intervenciós centrumunkba történt felvételig eltelt idő medián értékei a primeren és a szekunder beutalással felvett, valamint az összes betegnél (óra:perc) 


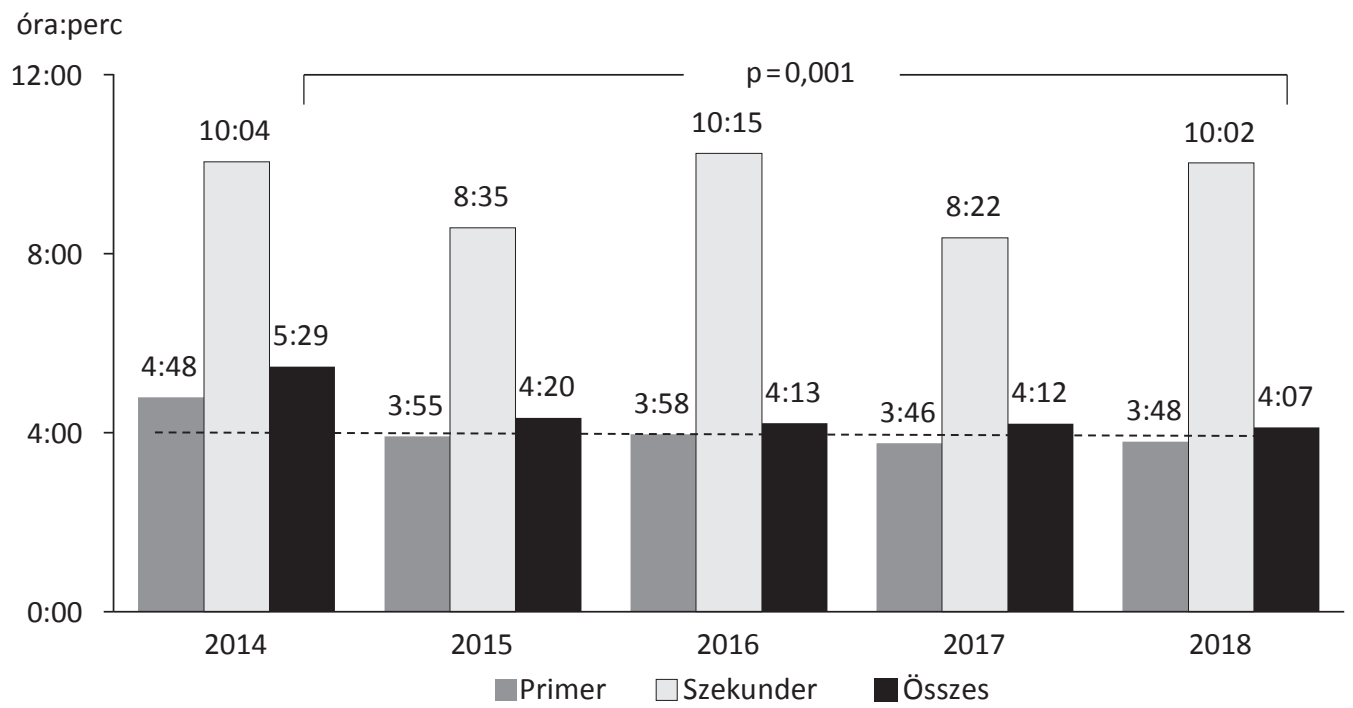

3. ábra $\quad$ A panasz kezdetétől a ballon nyitásáig eltelt idő medián értékei primer vagy szekunder felvételkor és az összes betegnél (óra:perc). A --- vonal a szívizommentés szempontjából klinikailag még megfelelőnek tartható 4 órás időt jelöli

2014 és 2018 között a panasz kezdetétől a koszorúéráramlás megindulását eredményező ballonnyitásig eltelt idő medián értéke rövidült ( 5:29 vs. 4:07 óra, $\mathrm{p}=0,001$ ), nagyrészt az első két évben. A későbbi években az adatok lényeges változást nem mutatnak. A primeren és a szekunderen felvett betegek közötti mintegy kétszeres időkülönbség nem módosult (3. ábra).

Az intervenciók végzésekor a behatolás helye a betegek több mint 96\%-ában a radialis artéria volt. Stentimplantációra az intervenciók során ötéves átlagban 97\% felett került sor; a DES-ek beültetési aránya 2014-ben mintegy 15\% volt, 2018-ra ez 96\% felettire változott (4. ábra).

Az eszközös légzés/keringés támogatást (IPPB, IABP, ECMO) igénylő betegek évenkénti aránya 8,2-10,613,9-7,6-8,4, 30 napos mortalitásuk 4,1-6,8-11,1$7,4-5,7 \%$ között változott. A két érték statisztikai korrelációt mutat (5. ábra).

A teljes ischaemiás idő alapján csoportokba sorolt betegek közül a fiziológiai szempontból kívánatos 2 órán és

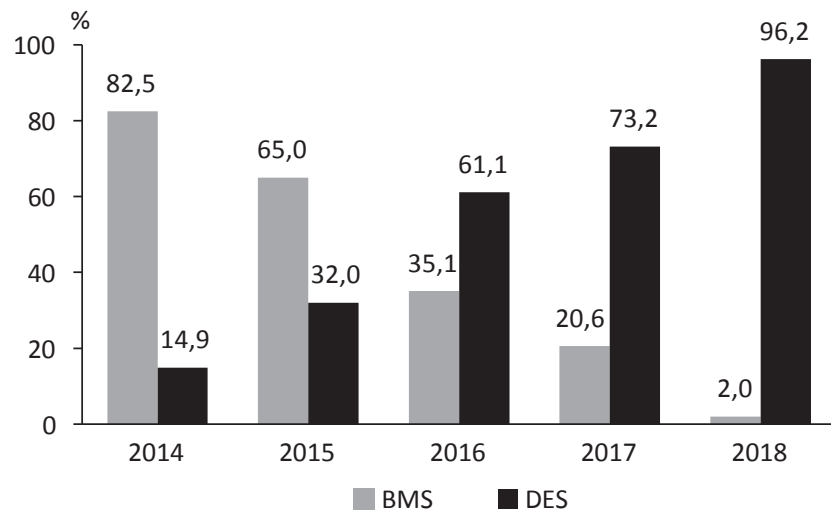

\begin{tabular}{l|l} 
4. ábra & $\begin{array}{l}\text { A beültetett stentek (BMS, illetve DES) \%-os arányának válto- } \\
\text { zása öt év alatt } \\
\text { BMS = fémhálós stent; DES = gyógyszerkibocsátó stent }\end{array}$
\end{tabular} a klinikai szempontból még megfelelőnek tekinthető 4 órán belüli arányok 2014 és 2018 között növekedést mutattak, de még az utóbbi sem sem érte el az 50\%-ot 2018-ra (6. ábra).

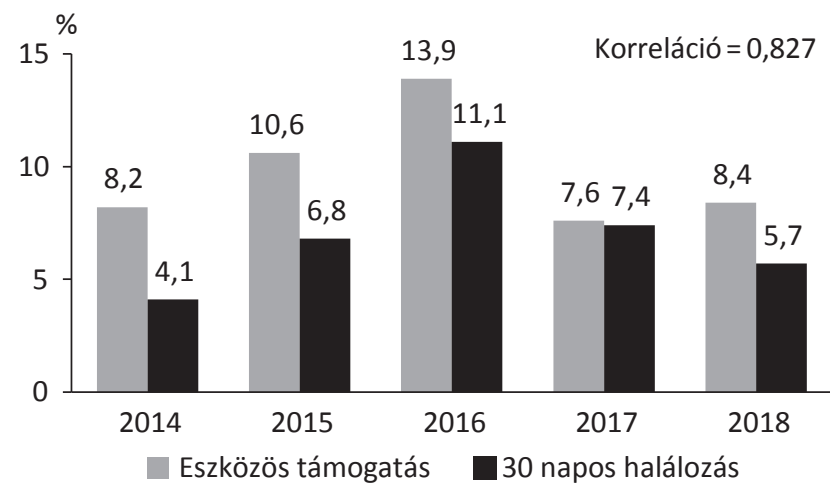

5. ábra $\mid$ A légzés/keringés támogatást igénylő és a 30 napon belül meghalt betegek százalékos aránya és a két érték korrelációja

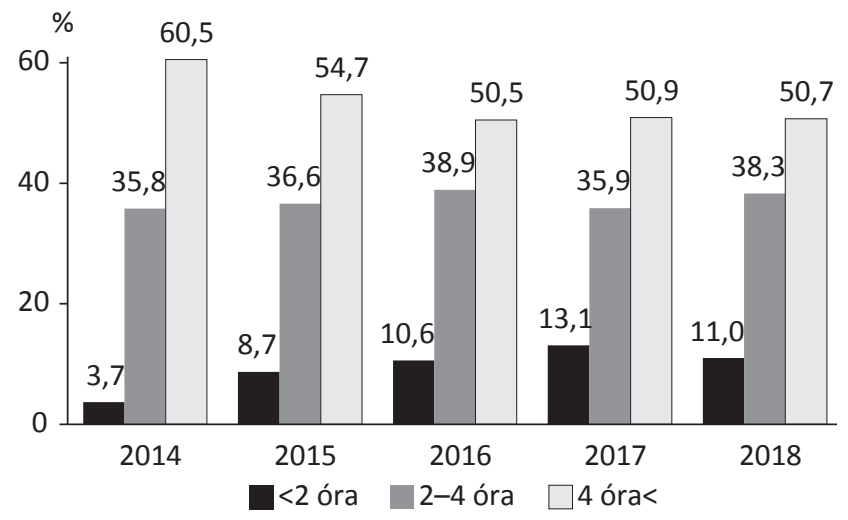

6. ábra a ballon nyitásáig eltelt idő alapján

pPCI $=$ primer percutan coronariaintervenció 


\section{Megbeszélés}

Régóta ismert, hogy akut koszorúér-elzáródásban a szívizom-károsodás mértéke a kollaterálishálózat fejlettsége és az ischaemiás prekondicionáltság mellett a koszorúér elzáródása és a rekanalizálódás közötti ischaemiás időtől függ [1-4]. A ballonos tágítást követően beültetett stent mérsékli az érfalsérülést és az intravasalis thrombus képződést, ezáltal az akut koszorúér-érelzáródás valószínűségét [5]. A BMS-beültetéshez képest DES beültetésekor kisebb az 'in stent' restenosis és az emiatt szükségessé váló revascularisatio aránya [6-8]. Nagy rizikójú betegekben (diabetes, többér-betegség) és/vagy komplikált szúkületekben (vékony érben vagy nem védett fötörzsben, vénás graftban, hosszú, bifurkációs, ostiumban levő szúkü̈letek) ennek aránya akár $25-30 \%$ is lehet $[9,10]$. A klinikai tapasztalatok növekedésével és az eszköz árának csökkenésével a DES-beültetés fokozatosan kiszorította a BMS használatát.

A pPCI korai időszakában több tanulmány igazolta, hogy az infarktusért felelős ér eszközös rekanalizálása gyorsabb és hatásosabb a gyógyszeres thrombolysishez képest: ballonos tágítás esetén általában nem marad viszsza nagy residualis szúkület, stentbeültetés esetén az áramlást akadályozó jelentős intimasérülés sem, és csökken a vérzéses szövődmények száma [11-13].

A radialis artérián történő behatolás több szempontból előnyös. A femoralis artérián végzetthez viszonyítva kisebb az érelzáródás és a lokális vérzés veszélye, a beteg korábban mobilizálható $[14,15]$.

Az Európai Kardiológiai Társaság [16] javaslata szerint ischaemiára utaló panaszok és perzisztáló ST-eleváció esetén 12 órán belül minden betegnél rekanalizációt kell végezni (IA indikáció), elsősorban PCI-t. Amennyiben a PCI-re nem kerülhet sor 120 percen belül, akkor fibrinolysis és utána katéteres értágításra alkalmas centrumba szállítás szükséges.

ST-eleváció hiányában, ha a tünetek kezdődő infarktusra utalnak, és hemodinamikai instabilitás vagy kardiogén sokk, életet veszélyeztető arrhythmia vagy szívmegállás, mechanikus komplikáció (kivéve szabadfali ruptura okozta haemopericardiumot), akut szívelégtelenség, illetve dinamikus ST-T változás áll fenn (IC indikáció). A tünetek kezdete utáni 12-48 órában a pPCI-indikáció IIaB. Tünetmentes betegnél 48 órán túl rutinszerü PCI nem javasolt, és általában halasztott stentbeültetés sem. pPCI-ben a rutinszerü thrombusaspiratio sem indokolt, növeli a stroke veszélyét, de nagy thrombus esetén elvégezhető.

AMI-ban végzett rekanalizációk elemzésekor tisztázódott, hogy az elzáródás és a rekanalizálás között eltelt idő nagyon fontos a klinikai következmények miatt, a betegek életkilátásait jelentősen befolyásolják [17-19]. Az időtényező fontos nemcsak a - részben logisztikai feladatot jelentő - kórházba szállításkor, hanem a szívkatéteres laboratóriumban végzett tevékenység során is $[20,21]$.
Az Európai Kardiológiai Társaság által 2017-ben javasolt időintervallumok:

\begin{tabular}{lr}
\hline Maximális idő az első EKG-tól a diagnózisig & $\leq 10$ perc \\
Maximális késés a STEMI-diagnózistól a pPCI-ig & $\leq 120$ perc \\
(a vezetődrót átjutása az elzáródott szakaszon) &
\end{tabular}

Maximális idő a kórházban történt primer megjelenéskor $\quad \leq 60$ perc a STEMI-diagnózistól a vezetődrótnak az elzáródott szakaszon való átjutásáig

Maximális idő áthelyezett betegnél a STEMI-diagnózis- $\quad \leq 90$ perc tól a vezetődrótnak az elzáródott szakaszon való átjutásáig

A legutóbbi időkig vitatott, hogy többér-betegségben csak az infarktusért felelőssé tehető laesio tágítandó-e, vagy a többi koszorúérben levő szignifikáns szúkület is. Több közlemény számol be ezen beavatkozások eredményéről saját beteganyag vagy metaanalízis kapcsán pró és kontra [22-25]. Az Európai Kardiológiai Társaság jelenlegi javaslata szerint rutineljárásként a nem 'culprit' laesiónak a kórházból történt kibocsátás előtti tágítása IIA indikációjú.

Betegeinknél a panasz kezdetétől az első egészségügyi kontaktusig eltelt idő medián értéke mintegy 2 óra, ez kevesebb a Jánosi és mtsai által közölt 205 percnél [26]. A centrumba szállítás idejének medián értéke az évek során fokozatosan rövidült, de az Európai Kardiológiai Társaság ajánlásához képest hosszú. Hasonló, a kívánatosnál hosszabb időtartamok találhatók más hazai tanulmányokban is [27, 28].

Az évenkénti bontásban vizsgált időintervallumok között a későbbi életkilátásokat jelentősen befolyásoló, a panasz kezdetétól a ballon nyitásáig eltelt totális ischaemiás idő [29] medián értéke anyagunkban az összes betegnél csökkent 2014-től 2015-ig, a további években értékelhető változás nincs. A tendencia hasonló a primeren felvett betegeknél is. A szekunderen felvetteknél az idő medián értéke többévi jelentős csökkenés után 2018ban ismét hosszabbodott. Összességében kedvező tendencia látható, de mértéke a kívánatosnál kisebb, és a csökkenés nem lineáris. A szekunderen felvett betegek medián értéke kétszerese a primeren felvettekének, tehát a szívizommentés valószínúsége kisebb, mint primer felvétel esetén. A klinikailag még elfogadható, négy órán belüli reperfúzió az esetek felében még 2018-ban sem valósult meg.

Anyagunkban a centrumban történt felvételtől a ballon nyitásáig eltelt idő 30 perc medián érték körüli, ugyanezen időszakban a Nemzeti Szívinfarktus Regiszter adataiban a hazai STEMI-s betegeknél medián értéke évenként vizsgálva ennél magasabb, 46-40 perc közötti. Primer felvételkor átlagunk az Európai Kardiológiai Társaság ajánlásában szereplő 60 perc alatt van, szekunder felvételkor 90 percet meghaladó, hosszabb az ajánlásnál. Súlyos betegeknél az intervenciós centrumba történt felvételtől a PTCA-s ballon nyitásáig eltelt idő jelentősen meghosszabbodhat a légzés/keringés támogatás igénye 
miatti, respirátorra és/vagy IABP-ra, ECMO-ra való helyezés miatt.

A légzés- és/vagy keringéstámogatásban részesült betegek aránya évenként változó. 8,2-10,6-13,9-7,6$8,4 \%$-os arányunk 2016 kivételével alacsonyabb, mint a Nemzeti Szívinfarktus Regiszter adatai szerinti 12,710,8-10,88-11,5-11,0\%-os országos átlag.

A 30 napon belüli halálozás aránya a vizsgált években nem csökkent értékelhetően. Az általunk kezelt betegek évenkénti 4,1-6,8-11,1-7,4-5,7\%-os aránya 2016 kivételével alacsonyabb ezen időszak 8,8-9,1-9,8-10,19,8\%-os hazai arányánál [29]. A halálozási ráták jelentős javulásának egyik lehetséges akadálya, hogy egyre több az akut infarktus mellett más súlyos betegségben is szenvedő vagy reanimáció után bekerült beteg, akiknél nagy rizikójú pPCI történik, légzés- és/vagy keringéstámogatás mellett [30-32].

Korábbi adatokból ismert, hogy a hazai populáció általános egészségi állapota nem kedvező a cardiovascularis betegségek prognózisa szempontjából [33]. Az Eurostat által értékelt 28 ország 2016-os adatai szerint az ischaemiás szívbetegség gyakoriságában a vizsgált országok között a 3. helyen voltunk, az átlagérték háromszorosával, infarktushalálozásban a 6 . helyen, az átlag másfélszeresével [34].

Nincs minden esetben van adatunk arra, hogy a beteg vagy hozzátartozója a panasz kezdetétől számítva menynyi idő múlva jelentkezik egészségügyi szolgáltatónál. A Nemzeti Szívinfarktus Regiszter adatai alapján a katéteres laboratóriummal nem rendelkező kórházból intervenciós centrumba való áthelyezés több mint másfél óra késést jelent [29]. Saját adataink hasonló időintervallumokat mutatnak, ebben a kérdésben évek óta nem látható jelentôs javulás.

Más országok tapasztalatát figyelembe véve, mind a szívizommentésben, mind a halálozás csökkentésében javíthatna a jelenlegi eredményeken a betegek gyorsabb bekerülése intervenciós centrumba. A panasztól a ballon nyitásáig terjedő ellátást összességében több szabadságfokú lengőrendszernek tekintve, a részletesebb felvilágosítás csökkenthetné az egészségügy által legkevésbé befolyásolható komponenst, azaz a beteg vagy a hozzátartozó jelentkezésének idejét az első egészségügyi szolgáltatónál. Részletes felvilágosítással csökkenne az intervenciós centrumokban a percutan intervencióba történő beleegyezés késése miatt a felvételtól a ballon nyitásáig eltelt idő is.

Anyagi támogatás: A kézirat elkészítése anyagi támogatásban nem részesült.

Szerzői munkamegosztás: Valamennyi szerző részt vett a közlemény alapját képező klinikai adatok kikeresésében és interpretálásában, V. L. és S. R. a statisztikai analízis végzésében is.

Érdekeltségek: A szerző́knek nincsenek érdekeltségeik.

\section{Irodalom}

[1] Cohen M, Rentrop P. Limitation of myocardial ischemia by collateral circulation during sudden controlled coronary artery occlusion in human subjects: a prospective study. Circulation 1986; 74: 469-476.

[2] Murry CE, Jennings RB, Reimer KA. Preconditioning with ischaemia: a delay of lethal cell injury in ischaemic myocardium. Circulation 1986; 74: 1124-1136.

[3] Kuzuyama T, Hoshida S, Yamashita N, et al. Delayed effects of sublethal ischaemia on the acquisition of tolerance to ischaemia. Circ Res. 1993; 72: 1293-2009.

[4] Figueras J, Otaeugui I, Marti G, et al. Area at risk and collateral circulation in a first acute myocardial infarction with occluded culprit artery. STEMI vs. non-STEMI patients. Int J Cardiol. 2018; 259: 14-19.

[5] Sigwart U, Puel J, Mirkovitch J, et al. Intravascular stents to prevent occlusion and restenosis after transluminal angioplasty. N Engl J Med. 1987; 316: 701-706.

[6] Stettler C, Wandel S, Allemann S, et al. Outcomes associated with drug-eluting and bare-metal stents: a collaborative network meta-analysis. Lancet 2007; 370: 937-948.

[7] James SK, Stenestrand U, Lindbäck J, et al., for the SCAAR Study Group. Long-term safety and efficacy of drug-eluting versus bare-metal stents in Sweden. N Engl J Med. 2009; 360: 1933-1945.

[8] Sabaté M, Brugaletta S, Cequier A, et al. Clinical outcomes in patients with ST-segment elevation myocardial infarction treated with everolimus-eluting stents versus bare-metal stents (EXAMINATION): 5-year results of a randomised trial. Lancet 2016; 387: 357-366.

[9] Voith L. Is it necessary to implant drug eluting stent in every dilated coronary artery stenosis? [Kell-e minden tágított koszorúér-szúkuületbe gyógyszerkibocsátó stentet ültetni?] Cardiol Hung. 2010; 40: 294-299. [Hungarian]

[10] Palmerini T, Biondi-Zoccai G, Della Riva D, et al. Clinical outcomes with drug-eluting and bare-metal stents in patients with ST-segment elevation myocardial infarction: evidence from a comprehensive network meta-analysis. J Am Coll Cardiol. 2013; 62: 496-504.

[11] Keeley EC, Boura JA, Grines CL. Primary angioplasty versus intravenous thrombolytic therapy for acute myocardial infarction: a quantitative review of 23 randomised trials. Lancet 2003; 361: 13-20.

[12] Grzybowski M, Clements EA, Parsons L, et al. Mortality benefit of immediate revascularization of acute ST-segment elevation myocardial infarction in patients with contraindications to thrombolytic therapy: a propensity analysis. JAMA 2003; 290: 1891-1898.

[13] Boersma E, Primary Coronary Angioplasty vs. Thrombolysis Group. Does time matter? A pooled analysis of randomized clinical trials comparing primary percutaneous coronary intervention and in-hospital fibrinolysis in acute myocardial infarction patients. Eur Heart J. 2006; 27: 779-788.

[14] Komócsi A, Ungi I, Kónyi A. Heart catheterisation from radial artery approach. [Szívkatéterezés arteria radialis behatolásból.] Akadémiai Kiadó, Budapest, 2009. [Hungarian]

[15] Valgimigli M, Gagnor A, Calabró P, et al., MATRIX Investigators. Radial versus femoral access in patients with acute coronary syndromes undergoing invasive management: a randomised multicentre trial. Lancet 2015; 385: 2465-2476.

[16] Ibanez B, James S, Agewall S, et al. 2017 ESC Guidelines for the management of acute myocardial infarction in patients presenting with ST-segment elevation: The Task Force for the management of acute myocardial infarction in patients presenting with ST-segment elevation of the European Society of Cardiology (ESC). Eur Heart J. 2018; 39: 119-177. 
[17] Boersma E, Maas AC, Deckers JW, et al. Early thrombolytic treatment in acute myocardial infarction: reappraisal of the golden hour. Lancet 1996; 348: 771-775.

[18] Gersh BJ, Antman EM. Selection of the optimal reperfusion strategy for STEMI: does time matter? Eur Heart J. 2006; 27 : 761-763.

[19] Terkelsen CJ, Sørensen JT, Maeng M, et al. System delay and mortality among patients with STEMI treated with primary percutaneous coronary intervention. JAMA 2010; 304: 763-771.

[20] Squire BT, Tamayo-Sarver JH, Rashi P, et al. Effect of prehospital cardiac catheterization lab activation on door-to-balloon time, mortality, and false-positive activation. Prehosp Emerg Care 2014; 18: 1-8.

[21] Nallamothu BK, Normand SL, Wang Y, et al. Relation between door-to-balloon times and mortality after primary percutaneous coronary intervention over time: a retrospective study. Lancet 2015; 385: 1114-1122.

[22] Cavender MA, Milford-Beland S, Roe MT, et al. Prevalence, predictors, and in-hospital outcomes of non-infarct artery intervention during primary percutaneous coronary intervention for STsegment elevation myocardial infarction (from the National Cardiovascular Data Registry). Am J Cardiol. 2009; 104: 507513 .

[23] Bangalore S, Toklu B, Wetterslev J. Complete versus culprit-only revascularization for ST-segment-elevation myocardial infarction and multivessel disease: a meta-analysis and trial sequential analysis of randomized trials. Circ Cardiovasc Interv. 2015; 8: e002142.

[24] Elgendy IY, Mahmoud AN, Kumbhani DJ, et al. Complete or culprit-only revascularization for patients with multivessel coronary artery disease undergoing percutaneous coronary intervention: a pairwise and network meta-analysis of randomized trials. JACC Cardiovasc Interv. 2017; 10: 315-324.

[25] Pavasini R, Biscaglia S, Barbato E, et al. Complete revascularization reduces cardiovascular death in patients with ST-segment elevation myocardial infarction and multivessel disease: systematic review and meta-analysis of randomized clinical trials. Eur Heart J. 2020; 41: 4103-4110.

[26] Jánosi A, Csató G, Pach FP, et al. Analysis of pre-hospital delay time of patients with myocardial infarction. [Szivinfarktus miatt kezelt betegek prehospitális késési idejének elemzése.] Orv Hetil. 2019; 160: 20-25. [Hungarian]

[27] Becker D, Merkely B. Current therapy of the acute coronary syndrome - 2016. [Akut coronaria szindróma ellátása - 2016.] Orv Hetil. 2016; 157: 1500-1506. [Hungarian]
[28] Jánosi A. Data on the state of care of the patients treated for myocardial infartion. Hungarian Myocardial Infarction Registry 2014-2018. [Adatok a szívinfarktus miatt kezelt betegek ellátásának helyzetéről. Nemzeti Szívinfarktus Regiszter 20142018.] Cardiol Hung. 2019; 49: 249-254. [Hungarian]

[29] Jánosi A, Erdôs G, Pach FP, et al. Prognostic significance of the total ischemic time in patients with ST-elevation myocardial infarction. [A teljes ischaemiás idő prognosztikus jelentôsége az ST-elevációval járó szívinfarktus miatt kezelt betegekben.] Orv Hetil. 2018; 159: 1113-1120. [Hungarian]

[30] Sjauw KD, Engström AE, Vis MM, et al. A systematic review and meta-analysis of intra-aortic balloon pump therapy in ST-elevation myocardial infarction: should we change the guidelines? Eur Heart J. 2009; 30: 459-468.

[31] Esper SA, Bermudez C, Dueweke EJ, et al. Extracorporeal membrane oxygenation support in acute coronary syndromes complicated by cardiogenic shock. Catheter Cardiovasc Interv. 2015: 86(Suppl 1): S45-S50.

[32] Voith L, Nowotta F, Skoda R, et al. Coronary angioplasty in serious myocardial infarction with device supported respiration and circulation. [Koszorúér-angioplasztika súlyos miokardiális infarktusban a légzés és a keringés eszközös támogatásával.] Cardiol Hung. 2020; 50: 106-110. [Hungarian]

[33] Jánosi A, Ofner P, Merkely B, et al. Short and long term prognosis of patients with myocardial infarction. Hungarian Myocardial Infarction Registry. [Szívinfarktus miatt kezelt betegek korai és késői prognózisa. Magyar Infarctus Regiszter Vizsgálat.] Orv Hetil. 2013; 154: 1297-1302. [Hungarian]

[34] European Commission - Eurostat Statistic Explained. Standardised death rates - diseases of the circulatory system, residents, 2016 (per 100000 male female inhabitants). Luxembourg City, 20 November, 2019 (latest revision). Available from: https:// ec.europa.eu/eurostat/statistics-explained/index.php?title=File:Standardised_death_rates_\%E2\%80\%94_diseases_of_the_ circulatory_system,_residents,_2016_(per_100_000_male_female_inhabitants)_Health2019.png\&oldid=459245 [accessed: Augustus 19, 2020].

(Voith László dr., Budapest, Városmajor u. 68., 1122 e-mail: laszlo.voith@gmail.com)

A cikk a Creative Commons Attribution 4.0 International License (https://creativecommons.org/licenses/by/4.0/) feltételei szerint publikált Open Access közlemény, melynek szellemében a cikk bármilyen médiumban szabadon felhasználható, megosztható és újraközölhető, feltéve, hogy az eredeti szerzỏ és a közlés helye, illetve a CC License linkje és az esetlegesen végrehajtott módosítások feltüntetésre kerülnek. (SID_1) 